\title{
Discharge of landslide-induced debris flows: case studies of Typhoon Morakot in southern Taiwan
}

\author{
J.-C. Chen and M.-R. Chuang \\ Dept. of Environmental and Hazards-Resistant Design, Huafan University, New Taipei, Taiwan \\ Correspondence to: J.-C. Chen (jinnchyi@cc.hfu.edu.tw)
}

Received: 28 November 2013 - Published in Nat. Hazards Earth Syst. Sci. Discuss.: 15 January 2014

Revised: - Accepted: 28 May 2014 - Published: 14 July 2014

\begin{abstract}
Three debris-flow gullies, the Hong-Shui-Xian (HSX), Sha-Xin-Kai (SXK), and Xin-Kai-Dafo (XKD) gullies, located in the Shinfa area of southern Taiwan, were selected as case studies on the discharge of landslide-induced debris flows caused by Typhoon Morakot in 2009. The inundation characteristics of the three debris flows, such as the debris-flow volume $V$, deposition area $A_{\mathrm{d}}$, and maximum flow depth, were collected by field investigations and simulated using the numerical modeling software FLO-2D. The discharge coefficient $c_{\mathrm{b}}$, defined as the ratio of the debrisflow discharge $Q_{\mathrm{dp}}$ to the water-flow discharge $Q_{\mathrm{wp}}$, was proposed to determine $Q_{\mathrm{dp}}$, and $Q_{\mathrm{wp}}$ was estimated by a rational equation. Then, $c_{\mathrm{b}}$ was calibrated by a comparison between the field investigation and the numerical simulation of the inundation characteristics of debris flows. Our results showed that the values of $c_{\mathrm{b}}$ range from 6 to 18 , and their values are affected by the landslide ratio $R_{\mathrm{L}}$. Empirical relationships for $c_{\mathrm{b}}$ versus $R_{\mathrm{L}}, Q_{\mathrm{dp}}$ versus $Q_{\mathrm{wp}}, Q_{\mathrm{dp}}$ versus $V$, and $A_{\mathrm{d}}$ versus $V$ are also presented.
\end{abstract}

\section{Introduction}

The debris-flow discharge is an important variable when designing debris-flow mitigation structures such as culverts, flumes, bridges, debris-flow barriers, and check dams. A debris-flow discharge can rarely be measured directly; thus, indirect methods are commonly used to estimate the discharges (Jakob, 2005). These methods include field observations, empirical methods, and numerical simulation methods. Field observations generally involve the determination of the flow velocity and cross-sectional measurements based on hydraulic formulae or channel surveys from flow superelevation, run up against obstacles, or channel characteristics (Chow, 1959; Hungr et al., 1984; Iverson et al., 1994). A debris-flow discharge can be correlated to the debris-flow volume or watershed characteristics. A variety of empirical equations relating the debris-flow peak discharge to the debris-flow volume (Mizuyama et al., 1992; Jitousono et al., 1996; Rickenmann, 1999) and the debris-flow peak discharge to the watershed characteristics (Bovis and Jakob, 1999) have been proposed to estimate the discharge. Attempts have been made to correlate the water-flow discharge $Q_{\text {wp }}$ with the debris-flow discharge $Q_{\text {dp }}$ (Takahashi, 1991; VanDine, 1985; Chen et al., 2008). The relationship between $Q_{\mathrm{dp}}$ and $Q_{\mathrm{wp}}$ was widely used in engineering planning because $Q_{\mathrm{wp}}$, which is related to the return period, can be easily determined by hydrologic analysis.

The assumed $Q_{\mathrm{dp}}$ is proportional to $Q_{\mathrm{wp}}$ and is expressed as

$Q_{\mathrm{dp}}=c_{\mathrm{b}} Q_{\mathrm{wp}}$,

where $c_{\mathrm{b}}$ is the discharge coefficient of the debris flow. $Q_{\text {wp }}$ is generally considered at its peak value for engineering planning and determined by a rational equation (Berti et al., 1999; Chen et al., 2008). $c_{\mathrm{b}}$ depends on the sedimentsupplementation conditions. The value of $c_{\mathrm{b}}$ can be high when a watershed has a high sediment supplementation. If the water contained in a debris flow has contributions solely from direct runoff, $Q_{\mathrm{dp}}$ is equivalent to the sum of $Q_{\mathrm{wp}}$ and the sediment discharge $Q_{\mathrm{s}}\left(Q_{\mathrm{s}}=c_{\mathrm{V}} Q_{\mathrm{dp}}\right.$, where $c_{\mathrm{V}}$ is the volumetric sediment concentration). $c_{\mathrm{b}}$ in Eq. (1) is expressed as

$c_{\mathrm{b}}=\left(1-c_{\mathrm{V}}\right)^{-1}$. 
Similar to Eq. (2a), an equation for the discharge coefficient for debris flows generated from gully-bed erosion was derived by Takahashi (1991), expressed as

$c_{\mathrm{b}}=\left(1-k_{\mathrm{c}}^{*} c_{\mathrm{V}}\right)^{-1}$,

where $k_{\mathrm{c}}^{*}=c_{*}^{-1}$, and $c_{*}$ is the volumetric concentration of the sediment layer on the gully bed. The value of $c_{\mathrm{V}}$ of the debris flow was generally greater than $20 \%$, and the maximum values of $c_{\mathrm{V}}$ observed ranged up to $0.9 c_{*}$ (Takahashi, 1991). On the basis of Eq. (2a), the minimum $c_{\mathrm{b}}=1.25$ if $c_{\mathrm{V}}=0.2$; on the basis of Eq. (2b), the maximum $c_{\mathrm{b}}=10$ if $c_{\mathrm{V}}=0.9 c_{*}$. This implies that the maximum $Q_{\mathrm{dp}}$ is 10 times that of $Q_{\mathrm{wp}}$, and the minimum $Q_{\mathrm{dp}}$ is 1.25 times that of $Q_{\mathrm{wp}}$.

The debris-flow discharge is largely dependent on factors such as the initiation mechanism (the discrete landslide point source versus the in-channel mobilization), the amount of debris entrained and deposited in the channel, and the channel morphology (Jakob, 2005). These factors may affect the value of $c_{\mathrm{b}}$ if Eq. (1) is used to compute the debris-flow discharge. However, the value of $c_{\mathrm{b}}$ calculated by Eqs. (2a) or (2b) is valid for in-channel debris flows (debris flows triggered by the in-channel mixing of water and sediment to form a debris flow) because it does not account for pointsource failure volumes. Hence, the value of $c_{\mathrm{b}}$ calculated by Eqs. (2a) or (2b) may underestimate the discharge of large landslide-induced debris flows. Owing to the lack of previous studies on the value of $c_{\mathrm{b}}$ related to the landslideinduced debris flow, three debris-flow events caused by Typhoon Morakot in the Shinfa area of southern Taiwan were selected as case studies to analyze the relationship between $Q_{\mathrm{dp}}$ and $Q_{\mathrm{wp}}$ using a numerical simulation method (the FLO-2D model). When the value of $c_{\mathrm{b}}$ with the estimated $Q_{\text {wp }}$ is provided or when the relationship between $Q_{\mathrm{dp}}$ and $Q_{\text {wp }}$ is developed, the debris-flow discharge can be determined. Knowing the debris-flow discharge is helpful for the planning of debris-flow hazard mitigation.

\section{Debris flows in the Shinfa area}

\subsection{Debris-flow hazards and rainfall}

\subsubsection{Debris-flow hazards}

In 2009, Typhoon Morakot brought extreme rainfall to southern Taiwan and caused many landslides and debris flows. The study area is located in the Shinfa village of the Liouguei District, Kaoshing City, in southern Taiwan (Fig. 1). Three landslide-induced debris-flow gullies, the Hong-Shui-Xian (HSX) gully, the Sha-Xin-Kai (SXK) gully, and the Xin-KaiDafo (XKD) gully in the village were selected as case studies. The three debris-flow events resulted from the majority of the landslide debris that originated upstream and entered the main stream of a gully, where it mixed with water and became a debris flow. The debris flow eroded the sidewalls of the stream, which entrained additional material that traveled further downstream. The debris-flow volume produced by the HSX gully ranged from 600000 to $1000000 \mathrm{~m}^{3}$, reporting an average of approximately $800000 \mathrm{~m}^{3}$ (SWCB, 2009). The deposition depth was over $5 \mathrm{~m}$. The debris-flow event buried the Shin-Shan hot-spring resort, damaged seven houses, and destroyed a road approximately $700 \mathrm{~m}$ in length (No. 133). The SXK gully produced a debris-flow volume of 800000 to $1100000 \mathrm{~m}^{3}$, reporting an average of approximately $1000000 \mathrm{~m}^{3}$ (SWCB, 2009), in downstream areas with a deposition depth of over $6 \mathrm{~m}$ in certain areas. The debris flow traveled downstream into the Shinfa village and Laolung River, where over 30 houses were buried. Tragically, the debris flow caused the death of four individuals, and 24 people were reported missing. The maximum deposition width on land approached $750 \mathrm{~m}$. For the debris flow in the XKD gully, the maximum deposition width was estimated to be $290 \mathrm{~m}$. Six houses were buried by the debris flow; fortunately, no injury was reported in this event.

\subsubsection{Rainfall}

The hourly and cumulative rainfall data collected from the Shinfa rain-gauge station, which is located approximately $2 \mathrm{~km}$ away from the SXK gully, is shown in Fig. 2. During Typhoon Morakot, an hourly maximum rainfall of $103 \mathrm{~mm}$ was recorded at 18:00 LT on 8 August 2009 (Fig. 2). The $24 \mathrm{~h}$ rainfall maximum of $1200 \mathrm{~mm}$ occurred over a period lasting from 03:00 LT on 8 August 2009 to 03:00 LT on $9 \mathrm{Au}-$ gust 2009. The return periods from $6 \mathrm{~h}$ to $48 \mathrm{~h}$ rainfall at the Shinfa rain-gauge station exceeded the past 200 years (WRA, 1999). Debris flows in the study area subsequently occurred within the period of the $24 \mathrm{~h}$ rainfall maximum. The three debris flows of the HSX, SXK, and XKD gullies almost occurred at the same time during 19:00 to 21:00 LT on $8 \mathrm{Au}-$ gust 2009. Landslides and sediments slowly began to move around 19:00 LT on 8 August 2009, 1 hour after the hourly rainfall reached its maximum. From 20:30 to 21:00 LT on 8 August 2009, the debris flow greatly expanded in size, flowed downstream, and buried downstream areas in sediment.

\subsection{Hydrogeological parameters}

Data pertaining to the watershed and inundation characteristics of the three debris flows, such as the landslide area, deposition area, and maximum flow depth, were collected. These data were identified using two basic stages. Firstly, information relating to the possible flow or depositional depth of debris flow was collected using media reports (from local newspapers and television news). The area relating to the landslide, and the deposition area of debris flow were also collected from a hazards map of the official report (SWCB, 2009), and from an interpretation of images such as aerial 

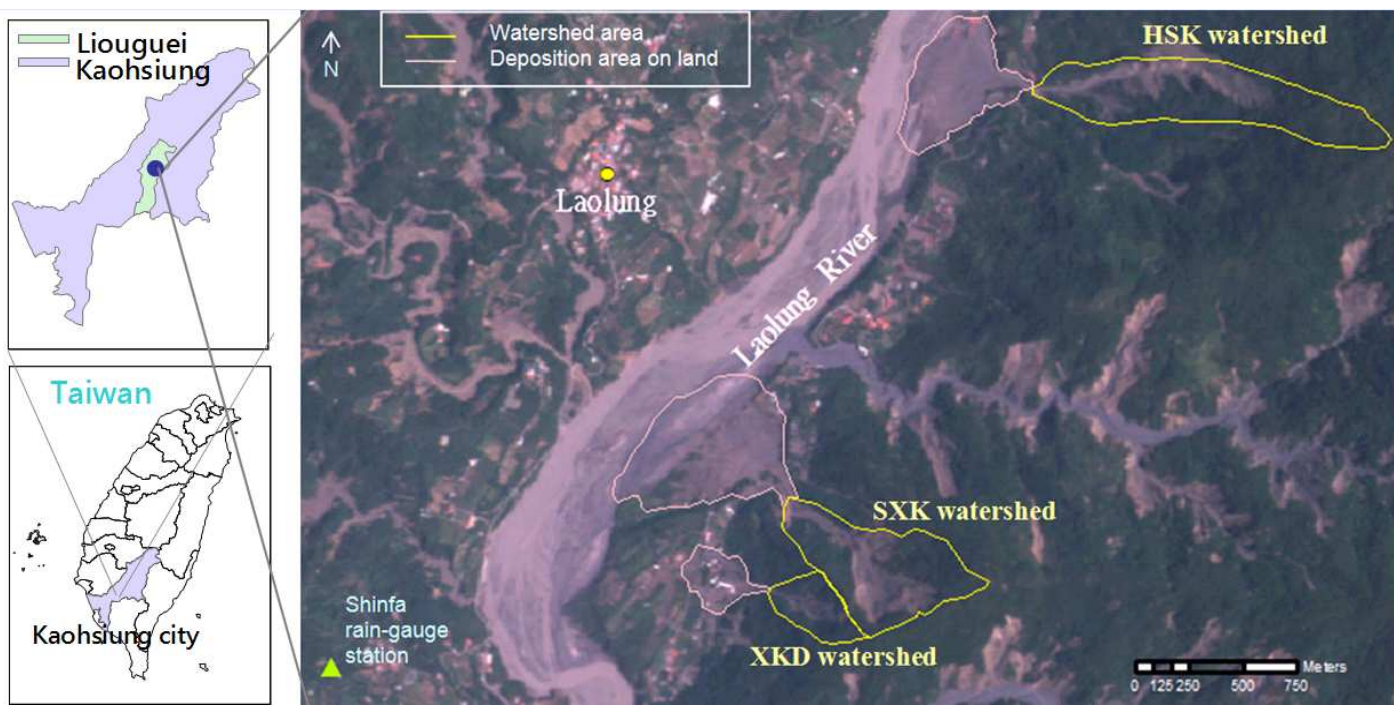

Figure 1. Locations of the HSX, SXK, and XKD gullies and the deposition areas of the debris flows during Typhoon Morakot in 2009.

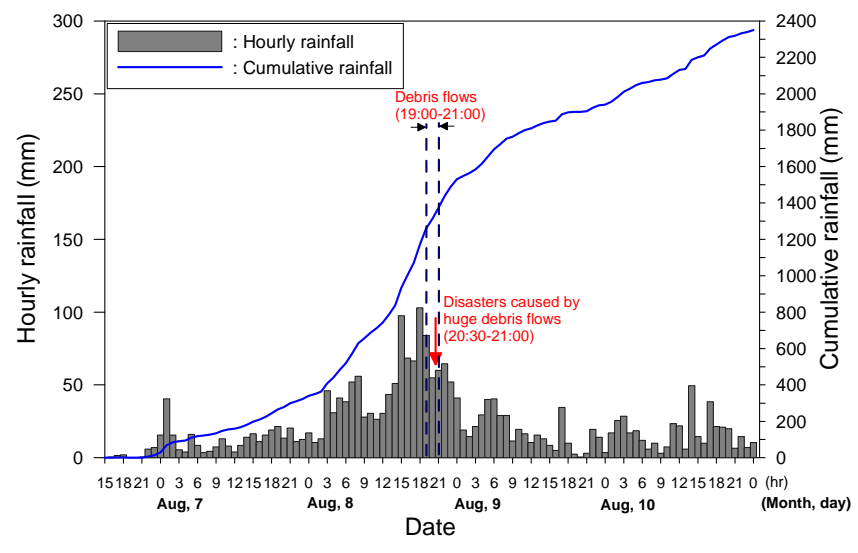

Figure 2. Rainfall data collected from 7 August 2009 to $10 \mathrm{Au}$ gust 2009 at the Shinfa rain-gauge station and the time that a debris flow was triggered.

photographs and satellite images (FORMOSAT2 images between May 2009 and September 2009) taken before and after Typhoon Morakot. The second stage involved conducting field investigations within 6 months of the event (which included interviewing local residents), to confirm certain landslide locations and inundation as reported in the first stage, and to thus investigate the flow or deposition depth of debris flow. Devices used for field surveying included cameras, GPS, and laser measurements. The maximum flow depth was obtained from the reports of resident witnesses, and by using the flow track that remained on buildings or trees in the field. Using these two stages, the landslide area, deposition area, and maximum flow depth of debris flow in the downstream area could be determined, which thus provided information for the subsequent simulation and verification.
Table 1 lists the watershed area measured at the fan apex $(A)$, the landslide area in $A\left(A_{\mathrm{L}}\right)$, the deposition area of debris flow $\left(A_{\mathrm{d}}\right)$, the ratio of $A_{\mathrm{L}}$ to $A$ (hereafter referred to as the landslide ratio $R_{\mathrm{L}}$ ), the maximum deposition width on land $(W)$, and the debris-flow volume $(V)$ for the three debris-flow gullies. $A_{\mathrm{L}}$ and $A_{\mathrm{d}}$ were determined by comparing the changes in the landslide area before and after Typhoon Morakot using the interpretation of images and field investigations. The landslide ratio $R_{\mathrm{L}}$ is a dimensionless parameter that represents the percentage of a landslide area $A_{\mathrm{L}}$ in watershed area $A$ due to the landslide-induced debris flow caused by Typhoon Morakot. $R_{\mathrm{L}}$ is an index that is generally used to evaluate the percentage area of a landslide area within a watershed, and has been used to assess landslide-prone areas in Taiwan (Wu and Chen, 2004; Wu et al., 2011). An index of the ruggedness of the catchment (Melton, 1965), the Melton ruggedness number $R_{\mathrm{M}}$ $(=H / \sqrt{A}$ in which $H=$ maximum elevation difference in $A$ ), and the classification of debris-flow magnitude using $V$ and $A_{\mathrm{d}}$ (Jakob, 2005) are also listed in Table 1. Jakob (2005) suggested that debris-flow magnitude can be divided into 10 classes between 1 (with $V<100 \mathrm{~m}^{3}$ and $A_{\mathrm{d}}<400 \mathrm{~m}^{2}$ ) and 10 (with $V>10^{9} \mathrm{~m}^{3}$ ) for bouldery debris flow. In the study area, HSX and SXK gullies are attributed to class 6 , and XKD gully is considered to be class 5 .

The three debris-flow gullies have a small watershed area ( $A<35$ ha), a high landside ratio $\left(R_{\mathrm{L}}>25 \%\right)$, and identical geological properties. The stratification in the study area is mainly composed of a Chau-chou layer (primarily composed of slate and argillite), and a Changchikeng layer (filled with deep-grey shale and light-grey sandstone). 
Table 1. Hydrogeological parameters for the three debris-flow gullies in the Shinfa area.

\begin{tabular}{lrrrrrrrrr}
\hline Name of gully & $A(\mathrm{ha})$ & $R_{\mathrm{M}}$ & $A_{\mathrm{L}}(\mathrm{ha})$ & $R_{\mathrm{L}}(\%)$ & $W(\mathrm{~m})$ & $A_{\mathrm{d}}\left(\times 10^{3} \mathrm{~m}^{2}\right)$ & $V\left(\times 10^{3} \mathrm{~m}^{3}\right)$ & $Q_{\mathrm{wp}}(\mathrm{cms})$ & Size class* \\
\hline HSX gully & 34.1 & 1.20 & 11.4 & 33.4 & 640 & $200-300$ & $600-1000$ & 7.8 & 6 \\
SXK gully & 29.7 & 0.41 & 12.1 & 40.7 & 750 & $340-450$ & $800-1100$ & 6.8 & 6 \\
XKD gully & 8.3 & 0.50 & 2.12 & 25.5 & 290 & 68 & $50-100$ & 1.9 & 5 \\
\hline
\end{tabular}

Note: $A=$ watershed area measured at fan apex; $R_{\mathrm{M}}=$ Melton ruggedness number $\left(R_{\mathrm{M}}=H / \sqrt{A}\right.$, in which $H=$ max. elevation difference in $\left.A\right) ; A_{\mathrm{L}}=$ landslide area in the watershed; $R_{\mathrm{L}}=$ landslide ratio $\left(R_{\mathrm{L}}=A_{\mathrm{L}} / A\right) ; W=$ max. deposition width on land; $A_{\mathrm{d}}=$ deposition area of debris flow, $A_{\mathrm{d}}$ in relation to HSX and SXK gullies was not possible to find exact values because this was altered during the flooding of the Laolung River; $V=$ debris-flow volume; $Q_{\mathrm{wp}}=$ estimated peak water discharge determined by the rational equation (Eq. 5) using $C=0.8$ and $I=103 \mathrm{~mm} \mathrm{~h}^{-1}$; *: size class (the classification of debris-flow magnitude) is based on the method suggested by Jakob (2005) using $V$ and $A_{\mathrm{d}}$.

\section{Method}

\subsection{FLO-2D model}

The FLO-2D (2009) routing model is software designed for two-dimensional mathematical modeling of water movement and flowing slope processes including debris flows. The FLO-2D model has been used successfully for debris-flow simulations by many researchers (e.g., Lin et al., 2005; Tecca et al., 2007; Hsu et al., 2010; Sodnik and Mikoŝ 2010), and it was used to analyze the landslide-induced debris flows on alluvial fans in this work. The FLO-2D model is physically based and takes into account the mass and momentum conservation of flows. The total friction slope $S_{\mathrm{f}}$ involved in the momentum equation of the FLO-2D model considers a combination of yield, viscous, collision, and turbulent stress components (O’Brien et al., 1993). $S_{\mathrm{f}}$ is expressed as

$$
S_{\mathrm{f}}=\frac{\tau_{\mathrm{y}}}{\rho h g}+\frac{k \eta v}{8 \rho h^{2} g}+\frac{n^{2} v^{2}}{h^{4 / 3}},
$$

where $\tau_{\mathrm{y}}$ and $\eta$ are, respectively, the Bingham yield stress and viscosity, $\rho$ is the flow (sediment and water mixture) density, $g$ is the gravitational acceleration, $h$ is the flow depth, $v$ is the depth-averaged velocity, $k$ is the laminar flow resistance coefficient, and $n$ is the pseudo-Manning coefficient that accounts for both the turbulent boundary friction and the internal collision stresses. The parameters related to $S_{\mathrm{f}}$, namely the friction parameters such as $\tau_{\mathrm{y}}, \eta, k$, and $n$ in Eq. (3), and the inflow hydrograph should be determined prior to debris-flow simulation.

\subsection{Simulation and analysis procedure}

\subsubsection{Preparation of the topographic and rainfall data and the selection of parameters}

1. Topographic data: topographic input data were obtained from a digital elevation model (DEM) of each analyzed watershed such as the HSX, SXK, and XKD gullies. The data had a resolution of $5 \mathrm{~m} \times 5 \mathrm{~m}$.

2. Rainfall data: rainfall data were collected from the Shinfa rain-gauge station. The maximum hourly rainfall data from this station were used to determine the peak water-flow discharges in our study gullies during Typhoon Morakot.

3. Parameters for simulation: the friction parameters used in this paper are described as follows:

\section{(1) The Bingham model parameters}

Consideration of rheological properties is very important when modeling debris flow, which generally contains a wide range of grain sizes from clay up to boulders. However, the rheological property of coarser particles contained in debris flow is usually difficult to measure from laboratory experiments. Thus, in some of applications, the Bingham model parameters $\left(\tau_{\mathrm{y}}\right.$ and $\left.\eta\right)$ were inferred from the measured rheology of fine material slurry samples (FLO-2D 2009). Bingham model parameters generally reflect the effect of fine particles or clay on the rheological properties of debris flow (Jan and Shen, 1992), and the collision effect from coarser particles within the debris flow may be reflected on values of $n$ (Rickenmann et al., 2006).

The Brookfield rotational viscometer and capillary viscometer have been commonly used to determine the rheological properties of debris-flow slurries in Taiwan (Jan et al., 1997; Wang, 2007), and the rheological parameters obtained from these viscometers have been applied to simulate debris flow and to classify the risk degree of hazardous debris-flow areas in Taiwan using the FLO-2D model (Lin et al., 2011, 2013). To determine the rheological parameters of the debris flow, soil samples with a particle diameter of less than $1 \mathrm{~mm}$ collected from the flow area of the HSX gully were analyzed in a laboratory experiment using a Brookfield rotational viscometer (type DV-III) (Chen et al., 2013). The relationship between the shear stress and the shear strain for the soil sample at various values of $c_{\mathrm{V}}$ was analyzed. The results showed that the rheological properties of the debrisflow slurries could be described by the Bingham model. The Bingham model parameters $\tau_{\mathrm{y}}$ (in dynes $\mathrm{cm}^{-2}$ ) and $\eta$ (in poise) both exponentially increased with an increase in $c_{\mathrm{V}}$, and these quantities are expressed as

$$
\begin{aligned}
\tau_{\mathrm{y}} & =0.459 e^{16.43 c_{\mathrm{v}}}, \\
\eta & =0.0485 e^{14.94 c_{\mathrm{v}}} .
\end{aligned}
$$


The results computed from these equations were consistent with the bounds reported in previous studies (FLO-2D, 2009; Dai et al., 1980; Fei, 1981). Equations (4a) and (4b) were used to determine the rheological parameters for the debrisflow simulations in this study.

\section{(2) The pseudo-Manning coefficient $n$}

$n$ is primarily a function of the channel or land-surface roughness, and the respective flow-resistance parameters of debris flows might additionally depend to some extent on the mechanical properties of the mixture (Rickenmann, 1999). $n$ with a value of 0.1 is usually used to analyze the debrisflow velocity by the Manning-Strickler equation (Pierson, 1986; PWRI, 1988; Rickenmann and Zimmermann, 1993); it $(n=0.1)$ was also used to simulate debris flows using the FLO-2D model (Calligaris and Zini, 2012). Generally, coarser-grained debris flows tend to require a higher value for $n$ than finer-grained mudflows. The value of $n$ can be determined from a mathematical model calibrated with an observed natural event (the back-calculated method). Rickenmann et al. (2006) showed that the values of the backcalculated $n$ varied in a limited range $n=0.07-0.16$ for a large number of debris-flow observations. The value of $n$ can also be determined from the FLO-2D (2009) manual, where values are suggested for different surfaces over which a debris flow moves, that is, $n=0.2$ was adopted for the debrisflow simulation of the Hrenovec watershed, Slovenia (Sodnik et al., 2009), and $n=0.18$ was used in the simulation of the Dolomites, Italy (Tecca et al., 2007). In this study, the values of $n$ were determined by referencing the FLO-2D manual and the previous studies mentioned above. The value of $n$ for the three debris-flow gullies in the Shinfa area ranged from 0.10 to 0.20 . Because the simulation results for the debris-flow inundation area were not significantly affected by the value of $n$ in the range of 0.10 to 0.20 (Chen et al., 2013), for simplicity, $n=0.15$ was adopted for use in this study.

\section{(3) The resistance parameter for laminar flow $k$}

The value of $k$ has a wide range, from 24 to 50000 . In the FLO-2D manual, a higher value of $k=2285$ is calibrated for modeling debris flows. The selection of a higher value for $k$ would not affect the simulations (Rickenmann et al., 2006), and the influence of the value of $k$ on the debris-flow simulation is not significant compared to the other parameters related to the flow resistance (Hsu et al., 2010). Thus, the value of $k=2285$ typically used in the literature (e.g., Tecca et al., 2007; Sodnik and Mikôs, 2010) was used to simulate debris flows.

\subsubsection{Determination of the discharge}

The debris-flow discharge was determined by Eq. (1), and $c_{\mathrm{b}}$ was calibrated by comparing the results obtained from numerical simulations to those obtained from the field investigations. The value for $Q_{\mathrm{wp}}$ is determined from the rational equation. This equation is probably the most used method for the design of water-flow discharges (Chow et al., 1988), and it is generally used to determine the design of water-flow discharges in a mountainous gully or debris-flow gully (Berti et al., 1999; Chen et al., 2008). The rational equation is

$Q_{\mathrm{wp}}=C I A / 360$,

where $C$ is the runoff coefficient, $I$ is the maximum hourly rainfall intensity $\left(\mathrm{mm} \mathrm{h}^{-1}\right)$, and $A$ is the watershed area (ha). In the study area, the value of $C$ ranges from 0.7 to 0.9 (SWCB 2005), and $C=0.8$ was used; $I=103 \mathrm{~mm} \mathrm{~h}^{-1}$ was the maximum hourly rainfall observed at the Shinfa rain-gauge station during Typhoon Morakot. $Q_{\mathrm{wp}}$ for the HSX, SXK, and XKD gullies was estimated as $7.8 \mathrm{~m}^{3} \mathrm{~s}^{-1}$, $6.8 \mathrm{~m}^{3} \mathrm{~s}^{-1}$, and $1.9 \mathrm{~m}^{3} \mathrm{~s}^{-1}$, respectively, according to the rational equation.

\subsubsection{Construction of the inflow hydrograph for debris flow}

1. Duration and sediment concentration

According to media reports and visits by residents, landslides and sediments slowly began to move around 7:00 p.m. on 8 August 2009. This escalated into a large and rapid debris-flow event from approximately 8:30 to 9:00 p.m. that had disastrous consequences. Thus, an inflow hydrograph with a duration of $2 \mathrm{~h}$ (7:00-9:00 p.m.) was used. The duration of the inflow hydrograph was divided into two stages for this study. Stage one (from 7:00 to $8: 30$ p.m.) was the stage in which the landslides gradually transferred material to highly viscous debris flows (with a high value of $c_{\mathrm{V}}$ ), and stage two (from 8:30 to 9:00 p.m.) was the stage of general debrisflow (with a lower value of $c_{\mathrm{V}}$ compared to stage one) formation. The ranges of $c_{\mathrm{V}}$ used for the two stages were obtained from reference values in the FLO-2D user's manual. Stage one used $c_{\mathrm{V}}=0.55-0.65$ for landslides or highly viscous debris flows, and stage two used $c_{\mathrm{V}}=0.48-0.55$ for general debris flows.

\section{Discharge coefficient}

The inflow hydrograph used in this study was assumed to be rectangular in shape with a duration $t$ of $2 \mathrm{~h}$, as shown in Fig. 3. The benefits for using a rectangular hydrograph shape are the simple shape itself and the ease in which the relationship between $Q_{\mathrm{dp}}$ and $Q_{\mathrm{wp}}$ may be discussed or developed. If the inflow hydrograph followed the shape in Fig. 3, $c_{\mathrm{b}}$ can be computed by $c_{\mathrm{b}}=V /\left(Q_{\mathrm{wp}} t\right)$. The possible values of $c_{\mathrm{b}}$ can be determined by using the ranges of $V, Q_{\mathrm{wp}}$ (as listed in Table 1$)$, and $t(=2 \mathrm{~h})$. The estimated $c_{\mathrm{b}}$ ranged from 11 to 18 for the HSX gully, 16 to 23 for the SXK gully, and 


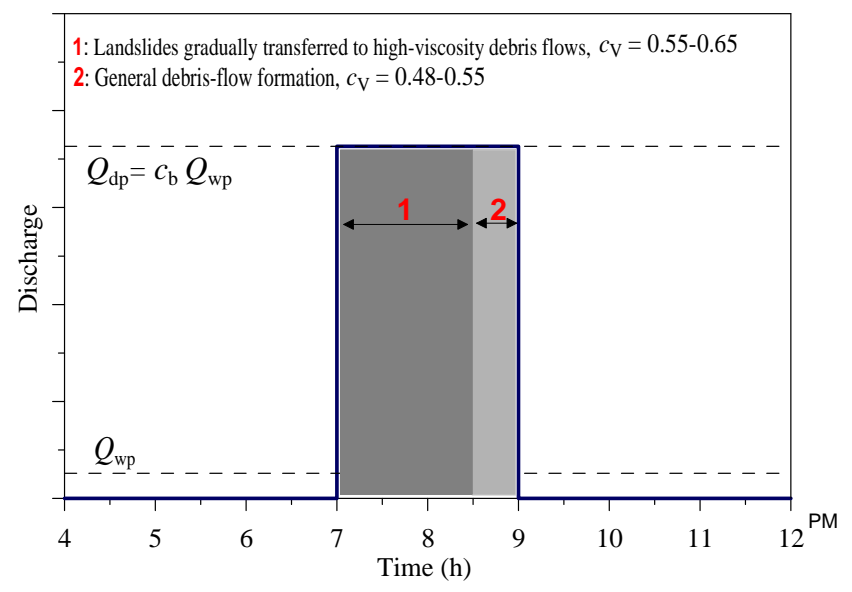

Figure 3. Schematic of the inflow hydrograph used for this study. The hydrograph was divided into stages 1 and 2 for the simulations of debris flows.

4 to 7 for the XKD gullies. On the basis of the estimated $c_{\mathrm{b}}$ ranges, the values of $c_{\mathrm{b}}$ were calibrated by comparing the results obtained from numerical simulations to those obtained from the field investigation.

$c_{\mathrm{V}}$ is an important factor related to the variation of the velocity of a debris flow, especially for $Q_{\mathrm{dp}}$ in the applied inflow hydrograph in this study, which was assumed to be constant. An inflow hydrograph with two stages of $c_{\mathrm{V}}$ values is helpful to reflect the phenomena observed in the field, which roughly indicated two stages of velocity for the landslide-induced debris flow, and it can be used to match some of the information related to the travel time of the debris flow from the field investigations. However, the real values of $c_{\mathrm{V}}$ are unknown and require calibration by comparing the inundation characteristics of a debris flow from numerical simulation to those from field investigations. The collected data from the field include the debris-flow volume, deposition area, maximum flow depth, and flow velocity or the travel time of debris flow. Owing to lack of observation data for the velocity, some information related to the travel time of the debris flow were collected.

\subsubsection{Debris-flow simulations and parameter calibration}

Because debris flows often impact downstream areas where the debris is ultimately deposited, modeling the deposition area of the debris flow was the primary aim of this study. The procedures used for determining the deposition area of the debris flow and the calibration parameters $\left(c_{\mathrm{b}}\right.$ and $\left.c_{\mathrm{V}}\right)$ are described as follows:

1. Determine the location of the debris-flow fan apex such as the mouth of the valley or the area downstream of the topographic apex. The location of the fan apex for the debris-flow gully was obtained from a topographical map and field investigations.

2. Assume a set of values for $c_{\mathrm{b}}$ and $c_{\mathrm{V}}$ (as discussed in Sect. 3.2.3) for determining the inflow hydrograph, as indicated in Fig. 3. Input the inflow hydrograph at the debris-flow fan apex and the various friction parameters such as $\tau_{\mathrm{y}}$ (Eq. 4a), $\eta$ (Eq. 4b), $k(=2285)$, and $n(=$ $0.15)$.

The inundation characteristics of a debris-flow gully was then computed via FLO-2D simulations. The results of the FLO-2D simulations were compared to the field conditions in terms of the travel time of the debris flow, the maximum flow depth, and the deposition area. If the simulated results were not in agreement with the field conditions, the inflow conditions (i.e., $c_{\mathrm{b}}$ and $c_{\mathrm{V}}$ ) were adjusted until the simulated results were similar to the conditions observed in the field investigation.

\section{Results}

\subsection{Calibrated parameters}

The travel times, the deposition areas, and maximum flow depths for the three debris-flow gullies were collected to calibrate $c_{\mathrm{b}}$ and $c_{\mathrm{V}}$ of the debris flows. Some information related to the travel time of the debris flow include a small percent of the mass or sediment that slowly flowed and blocked the road (No. 133) between 7:00 and 8:00 p.m. on 8 August 2009, and the debris flow rapidly inundated the downstream area and affected houses or buildings between 8:30 and 9:00 p.m. on 8 August 2009 (it could have attained the maximum velocity in this period). The deposition area of the debris flows were identified through the interpretation of aerial photographs, satellite images, and field investigations. The maximum flow depth (MD) was obtained in two ways: from the testimony of resident witnesses, and from the flow track remaining on buildings or trees in the field.

\subsubsection{HSX gully}

Figure 4 shows the results of the deposition area from the numerical simulation using the inflow hydrograph with $c_{\mathrm{b}}=$ 14 , where the values of $c_{\mathrm{V}}$ for stages one and two were 0.64 and 0.55 , respectively. The simulated results and field investigation show that part of the deposited sediment caused by the HSX debris flow flows into the Laolung River. The actual deposition area into the Laolung River was not able to be obtained from the field investigation because it was destroyed by the flooding of the Laolung River. Thus, the deposition area on land from the field investigation was used for comparison with the numerical simulation. Figure 4 shows that the deposition area on land from the simulation was close to that from field investigation. 


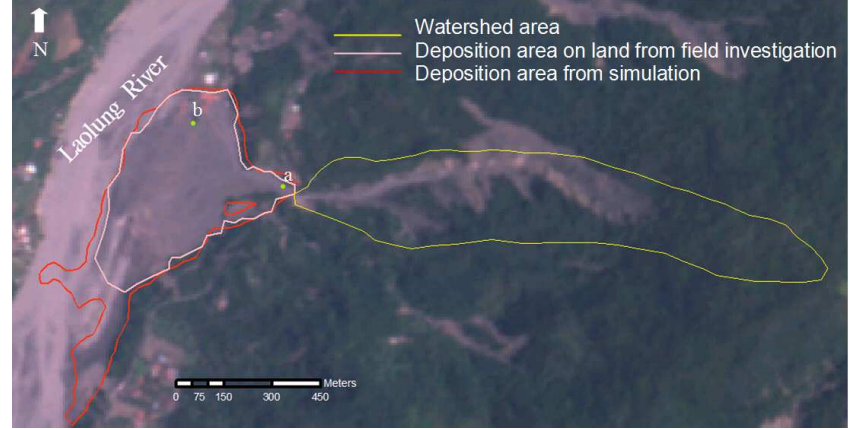

Figure 4. Comparison of the deposition area between the simulation and the field investigation. A few maximum flow depths are indicated by green circles collected from the field investigation of the HSX gully.

The simulated results also show that the debris flow rapidly inundated the downstream area between 8:30 and 9:00 p.m. on 8 August 2009 with a maximum velocity of $4.2 \mathrm{~m} \mathrm{~s}^{-1}$. The maximum deposition depth in the debrisflow deposition area was greater than $6 \mathrm{~m}$. The computed debris-flow volume from the numerical simulation is around $790000 \mathrm{~m}^{3}$, which is close to the value of approximately $800000 \mathrm{~m}^{3}$ estimated by SWCB (2009).

\subsubsection{SXK and XKD gullies}

Following the same procedure as in the analysis of the HSX gully, the calibrated values of the inflow hydrograph were $c_{\mathrm{b}}=18, c_{\mathrm{V}}=0.64$ for stage one, and $c_{\mathrm{V}}=0.50$ for stage two for the SXK gully; and $c_{\mathrm{b}}=6, c_{\mathrm{V}}=0.65$ for stage one, and $c_{\mathrm{V}}=0.55$ for stage two for the XKD gully. Table 2 summarizes the calibrated parameters used for the debris-flow simulations of the three case studies of the Shinfa area. With the calibrated values, Fig. 5 shows that the deposition areas of the SXK and XKD gullies from the simulations are similar to those from the field investigations.

The simulated results also show that two debris flows inundated downstream areas with houses and buildings at 8:309:00 p.m. on 8 August 2009, which is in rough agreement with information from the local populace. The SXK debris flow attained a maximum velocity of $6.6 \mathrm{~m} \mathrm{~s}^{-1}$, and the XKD debris flow attained a maximum velocity of $2.1 \mathrm{~m} \mathrm{~s}^{-1}$. The higher velocity of the SXK debris flow caused over 30 houses to be buried, the deaths of 4 people, and 24 missing people. Compared to the SXK debris flow, the damage caused by the XKD debris flow was slightly lower owing to the lower velocity of the XKD debris flow. The major building (Great Buddha in shape) in the XKD gully was nearly complete, and no injuries were reported in this event. The simulated debrisflow volumes $V$ were around $880000 \mathrm{~m}^{3}$ for the SXK gully and $82000 \mathrm{~m}^{3}$ for XKD gully.

The maximum flow depths (MDs) of debris flows in the field were also collected. Figure 6 shows the MDs for the

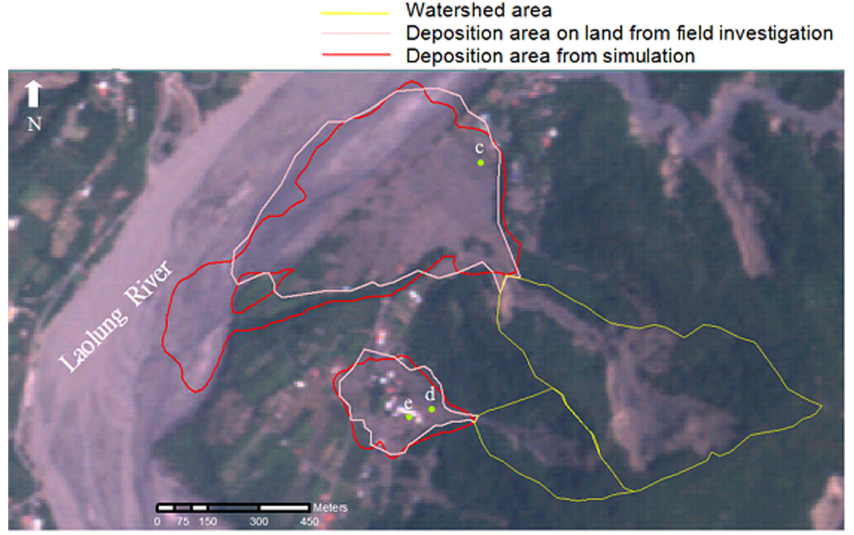

Figure 5. Comparison of the deposition areas between the simulations and the field investigations. A few maximum flow depths are indicated by green circles collected from the field investigations of the SXK and XKD gullies.

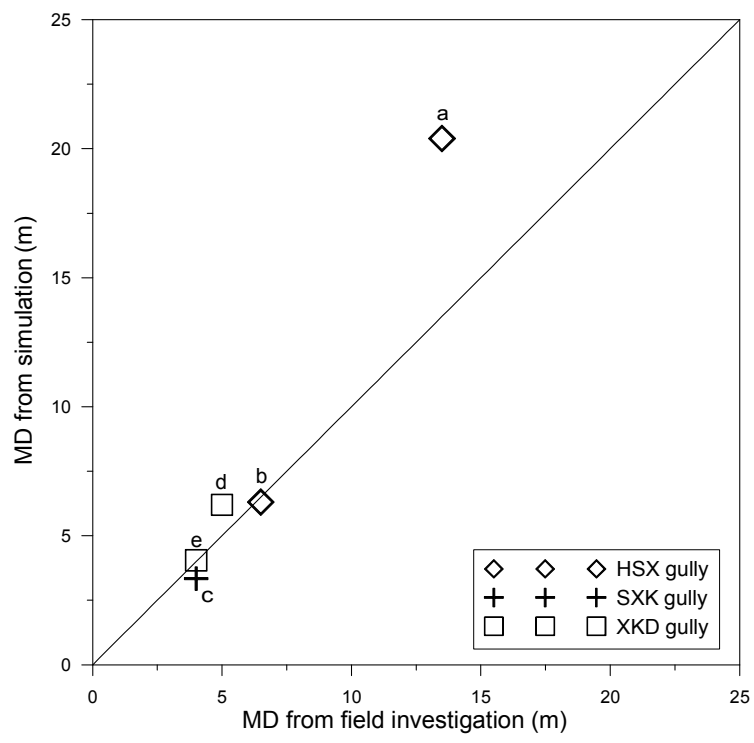

Figure 6. Maximum flow depths (MDs) of debris flows from numerical simulations compared to those from field investigations in the HSX, SXK, and XKD gullies. Locations of points a, b, c, d, and e are shown in Figs. 4 and 5.

simulations and field investigations in HSX, SXK, and XKD gullies; the location of points a, b, c, d, and e therein are indicated in Figs. 4 and 5. The cross section of point "a" (near the fan apex of the HSX gully in Fig. 4) is shown to be expanded due to riverbank erosion during the debris flow. Because the FLO-2D model is unable to simulate the erosion process, the MD at point " $a$ " in the simulation differs from that in the field investigation. In general however, MDs for the simulation for the three gullies are almost in agreement with those from the field investigation. 


\subsection{Relationship between the debris-flow discharge and the water-flow discharge}

According to the calibrated values of $c_{\mathrm{b}}$ (in the range from 6 to 18 ) in Table 2 for the three gullies in the Shinfa area, $Q_{\mathrm{dp}}$ corresponding to $Q_{\mathrm{wp}}$ was calculated from Eq. (1) and is plotted in Fig. 7. Data for $Q_{\mathrm{dp}}$ versus $Q_{\mathrm{wp}}$ was also used to compare with the data from previous studies. Table 3 lists the sources or methods for the determination of $Q_{\mathrm{dp}}$ and $Q_{\mathrm{wp}}$ from previous studies. The data from previous studies include the field observation data on debris flows in the Jiangjia Gully in China (Wu et al., 1990), field experiments on debris flows at the Chemolgan test site in Kazakhstan (Rickenmann et al., 2003), and the estimated peak debris-flow discharges in the Howe Sound in British Columbia (VanDine, 1985) and in the Dolomite Mountains in northeastern Italy (Berti et al., 1999). Data relating to the maximum debris-flow discharge and the 100-year-design water discharge of the Predelica torrent in the Log pod Mangartom village, Slovenia, in November 2000 (Četina et al., 2006; Mikoš et al., 2007) were also collected. Figure 7 shows that $Q_{\mathrm{dp}}$ increases with increasing $Q_{\text {wp }}$. The upper and lower bounds for the relationships for $Q_{\mathrm{dp}}$ associated with $Q_{\mathrm{wp}}$ are approximately expressed by

$Q_{\mathrm{dp}}=40 Q_{\mathrm{wp}}$ for the upper bound,

$Q_{\mathrm{dp}}=5 Q_{\mathrm{wp}}$ for the lower bound.

These equations imply that the values of $c_{\mathrm{b}}$ range from 5 to 40. All data in this work (labeled 1, 2, and 3 in Fig. 7) agreed with the ranges from previous studies. The upper bound for $Q_{\mathrm{dp}}$ versus $Q_{\mathrm{wp}}$ in our case studies is close to $Q_{\mathrm{dp}}=20 Q_{\mathrm{wp}}$.

\subsection{Relationship between the discharge coefficient and the landslide ratio}

The values of $c_{\mathrm{b}}$ at different areas may be different owing to different hydrogeological conditions such as rainfall, watershed area, landslide area, and topographical and geological properties. The three debris-flow gullies in this study have similar rainfall and geological conditions. Figure 8 shows the relationship between $c_{\mathrm{b}}$ and $R_{\mathrm{L}}$ in this study, and the fitted equation with determination coefficient $R^{2}=0.96$ can be expressed as

$c_{\mathrm{b}}=0.0028 R_{\mathrm{L}}^{2.4}$.

Values of $c_{\mathrm{b}}$ increase with an increase in $R_{\mathrm{L}}$. This result means that $c_{\mathrm{b}}$ was affected by the large sediment supplement brought in from the landslides and increased its value. In addition to direct runoff, the water flow that initiated the debris flow likely originated from the groundwater or the water contained in sediments that were brought in by the landslides. Furthermore, the water flow could have been blocked by the sediment brought in by landslides, which would have rapidly increased the water storage in the watershed. A high debrisflow discharge may have resulted when the stored water combined with sediments burst over a short period of time. A

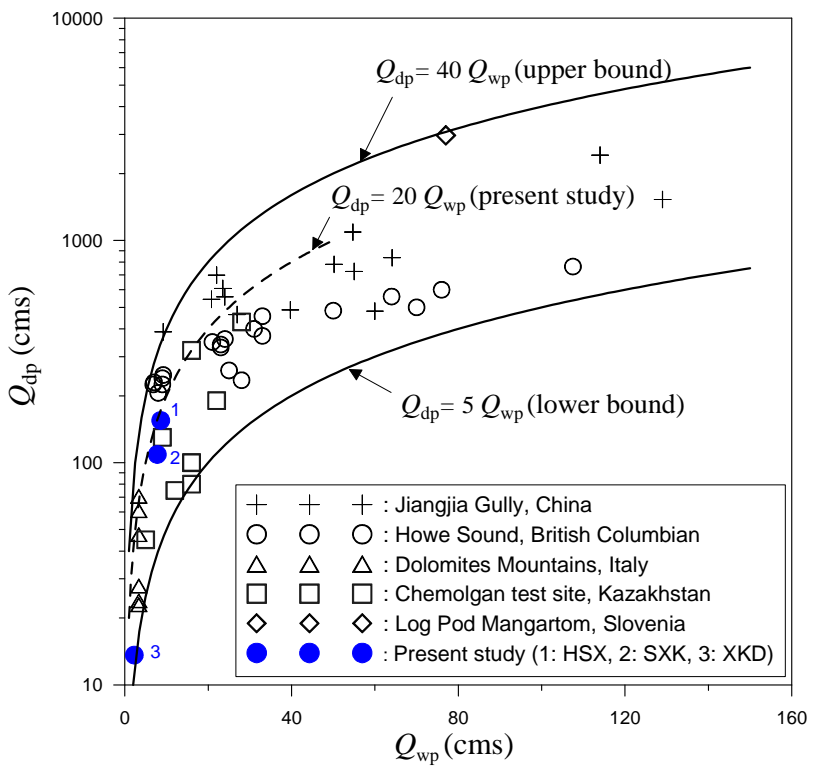

Figure 7. Relationship between the debris-flow discharge $Q_{\mathrm{dp}}$ and the water-flow discharge $Q_{\mathrm{wp}}$.

high debris-flow discharge will be reflected by a higher discharge coefficient $\left(c_{\mathrm{b}}\right)$. For gully-bed instability or erosioninduced debris flows (the in-channel debris flow), the maximum value of $c_{\mathrm{b}}$ could be as high as 10 based on the viewpoint of Takahashi (1991), while the value of $c_{\mathrm{b}}$ for high$R_{\mathrm{L}}$-induced debris flows (>30\%) could exceed the bound $\left(c_{\mathrm{b}}=10\right)$ proposed by Takahashi (1991), as shown in Fig. 8. This means that the value of $c_{\mathrm{b}}$ for the debris-flow type that forms from landslides is not able to be determined merely from Eqs. (2) or (3). The case studies on the value of $c_{b}$ for landslide-induced debris flows in this work could be helpful for determining the debris-flow discharge in the engineering or planning of debris-flow hazard mitigation.

\subsection{Other empirical equations relating the debris-flow discharge}

\subsubsection{Debris-flow discharge versus debris-flow volume}

Various empirical equations relating the debris-flow peak discharge $Q_{\text {dp }}$ to the debris-flow volume $V$ have been proposed by many researchers (Mizuyama et al., 1992; Jitousono et al., 1996; Bovis and Jakob, 1999; Rickenmann, 1999) and summarized by Jakob (1995) for an indirect determination of $Q_{\mathrm{dp}}$, as shown in Table 4 . These equations are plotted in Fig. 9. All equations in Fig. 9 have a large variability due to the variable debris flow rheology (muddy vs. bouldery flows), initiation mechanism, and/or channel morphology (Jakob, 1995). Therefore, all empirical correlations need to be verified regionally. The fitted equation for $Q_{\mathrm{dp}}$ vs. $V$ in this study is also shown in Fig. 9 for comparison, and is 
Table 2. Calibrated parameters used for debris-flow simulations of the three gullies in the Shinfa area.

\begin{tabular}{lrrrrrr}
\hline Name of gully & $c_{\mathrm{b}}$ & $c_{\mathrm{V}}$ at stage 1 & $c_{\mathrm{V}}$ at stage 2 & $Q_{\mathrm{dp}}(\mathrm{cms})$ & $V\left(\mathrm{~m}^{3}\right)$ & $A_{\mathrm{d}}\left(\mathrm{m}^{2}\right)$ \\
\hline HSX gully & 14 & 0.64 & 0.55 & 109.2 & 790000 & 271626 \\
SXK gully & 18 & 0.64 & 0.50 & 122.4 & 880000 & 406926 \\
XKD gully & 6 & 0.65 & 0.55 & 11.4 & 82000 & 71372 \\
\hline
\end{tabular}

Note: $Q_{\mathrm{dp}}$ was determined by Eq. (1) using the calibrated $c_{\mathrm{b}}$. Other parameters related to the flow resistance adopted in this study were $n=0.15$ and $k=2285$.

Table 3. Summary of the estimation of the debris-flow discharge and water-flow discharge from previous studies.

\begin{tabular}{|c|c|c|c|}
\hline Location & $Q_{\mathrm{dp}}$ & $Q_{\mathrm{wp}}$ & Source \\
\hline $\begin{array}{l}\text { The Chemolgan test } \\
\text { site, Kazakhstan }\end{array}$ & $\begin{array}{l}\text { Determined from field exper- } \\
\text { iments on debris flows for } \\
\text { measurements and calcula- } \\
\text { tions of debris-flow surges. }\end{array}$ & $\begin{array}{l}\text { Debris flows were artificially triggered } \\
\text { by releasing water from a reservoir. } \\
\text { A total of eight experiments on debris } \\
\text { flows were carried out between } 1972 \\
\text { and } 1991 . Q_{\mathrm{wp}} \text { was measured by con- } \\
\text { trolling the inflow gate from the reser- } \\
\text { voir. }\end{array}$ & $\begin{array}{l}\text { Rickenmann et } \\
\text { al. (2003) }\end{array}$ \\
\hline Jiangjia Gully, China & $\begin{array}{l}\text { Determined from observation } \\
\text { data of debris-flow surges for } \\
\text { a debris event. }\end{array}$ & $\begin{array}{l}Q_{\text {wp }} \text { was determined from the hydro- } \\
\text { logic design handbook in the study area } \\
\text { using the watershed characteristics and } \\
\text { the rainfall intensity of the rainfall event } \\
\text { triggering the debris flow. }\end{array}$ & Wu et al. (1990) \\
\hline $\begin{array}{l}\text { Gully in the Dolomite } \\
\text { Mountains, northeast- } \\
\text { ern Italy }\end{array}$ & $\begin{array}{l}\text { Estimated from supereleva- } \\
\text { tions of lateral deposits or } \\
\text { mudlines left by the peak dis- } \\
\text { charge using a superelevation } \\
\text { formula. }\end{array}$ & $\begin{array}{l}Q_{\text {wp }} \text { was estimated using a rational } \\
\text { equation using the watershed character- } \\
\text { istics and rainfall intensity of the rainfall } \\
\text { event triggering debris flow in the study } \\
\text { area. }\end{array}$ & Berti et al. (1999) \\
\hline $\begin{array}{l}22 \text { creeks along the } \\
\text { Howe Sound, British } \\
\text { Columbia }\end{array}$ & $\begin{array}{l}\text { Estimated from the superele- } \\
\text { vations of lateral deposits or } \\
\text { the mudlines left by the peak } \\
\text { discharge using a supereleva- } \\
\text { tion formula. }\end{array}$ & $\begin{array}{l}Q_{\text {wp }} \text { was determined by hydrologic } \\
\text { analysis using a 200-year water- } \\
\text { discharge design. }\end{array}$ & $\begin{array}{l}\text { Hungr et al. (1984), } \\
\text { VanDine (1985) }\end{array}$ \\
\hline
\end{tabular}

as follows:

$Q_{\mathrm{dp}}=0.00014 \mathrm{~V}$.

However, the value of $Q_{\mathrm{dp}}$ corresponding to $V$ in Eq. (9) is smaller than that seen in the previous study's relationships. This is considered to be attributed to the small watershed area and the high landslide ratio for the study's three gullies, in addition to the long travel time of the debris flows (last around $2 \mathrm{~h}$ ). $Q_{\text {dp }}$ is generally small for a debris flow generated from a small watershed area with a long travel time; and a high landslide ratio $R_{\mathrm{L}}$ can result in a larger $V$, as shown in Fig. 10 . In addition, $V$ has a tendency to increase with an increase of $R_{\mathrm{L}}$. Furthermore, for the modeling work herein, the discharge at the fan apex was assumed to have a rectangular form (to easily compute $c_{\mathrm{b}}$ and to understand the relationship between $Q_{\mathrm{dp}}$ and $Q_{\mathrm{wp}}$ in application), and the real peak value of $Q_{\mathrm{dp}}$ may therefore have been underestimated. Other factors, such as the different debris flow rheology, initiation mechanism, and/or the channel morphology also may affect the relationship between $Q_{\mathrm{dp}}$ and $V$.

\subsubsection{Deposition area versus debris-flow volume}

The deposition area by debris flow influences land-use decisions and the selection and design of mitigation measures. Iverson et al. (1998) and Griswold (2004) found a correlation between deposition area $A_{\mathrm{d}}$ and debris-flow volume $V$, which can be expressed as

$A_{\mathrm{d}}=\lambda V^{2 / 3}$,

in which the empirical coefficient is $\lambda=200$ for volcanic debris flows, and $\lambda=20$ for non-volcanic debris flows. However, the values of $\lambda$ may differ for different site conditions due to the various sedimentary properties, and could 
Table 4. Empirical equations of debris-flow peak discharge $Q_{\mathrm{dp}}$ versus the debris-flow volume $V$ from previous research.

\begin{tabular}{lll}
\hline Number & Equation & Source \\
\hline 1 & $Q_{\mathrm{dp}}=0.135 V^{0.78}$ (bouldery debris flow) & Mizuyama et al. (1992) \\
2 & $Q_{\mathrm{dp}}=0.019 V^{0.79}$ (muddy debris flow) & Mizuyama et al. (1992) \\
3 & $Q_{\mathrm{dp}}=0.006 V^{0.83}$ (volcanic debris flow) & Jitousono et al. (1996) \\
4 & $Q_{\mathrm{dp}}=0.04 V^{0.90}$ (bouldery debris flow) & Bovis and Jakob (1999) \\
5 & $Q_{\mathrm{dp}}=0.003 V^{1.01}$ (volcanic debris flow) & Bovis and Jakob (1999) \\
6 & $Q_{\mathrm{dp}}=0.1 V^{0.83}$ & Rickenmann (1999) \\
\hline
\end{tabular}

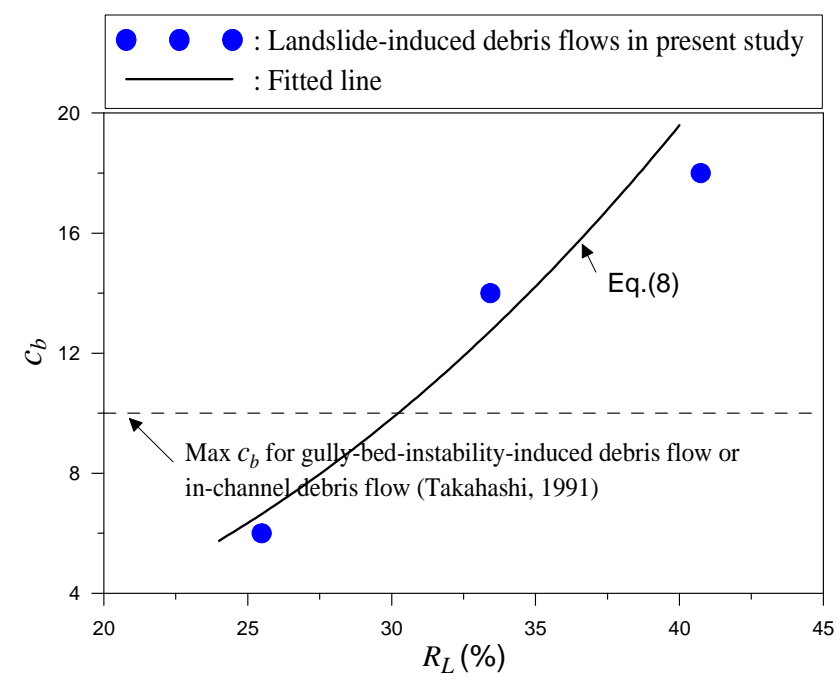

Figure 8. Relationship between the discharge coefficient $c_{\mathrm{b}}$ and the landslide ratio $R_{\mathrm{L}}$.

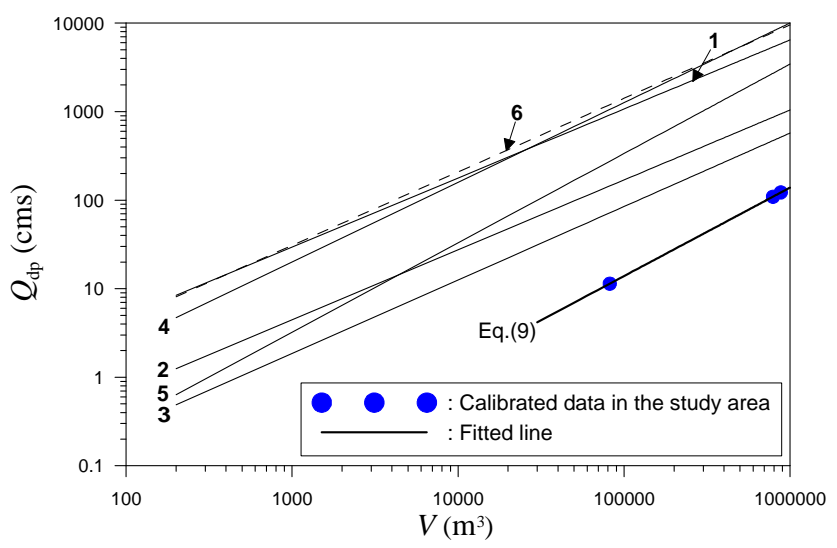

Figure 9. Relationship between debris-flow discharge $Q_{\mathrm{dp}}$ and debris-flow volume $V$. Numbers (from 1 to 6 ) corresponding to individual equations are indicated in Table 4.

therefore result in a value of $\lambda$ between 20 and 200 (Jakob, 1995). Using the calibrated data set in this study (listed in Table 2), a line fitted by Eq. (10) shows the value of $\lambda$ to be approximately 40 (Fig. 11).

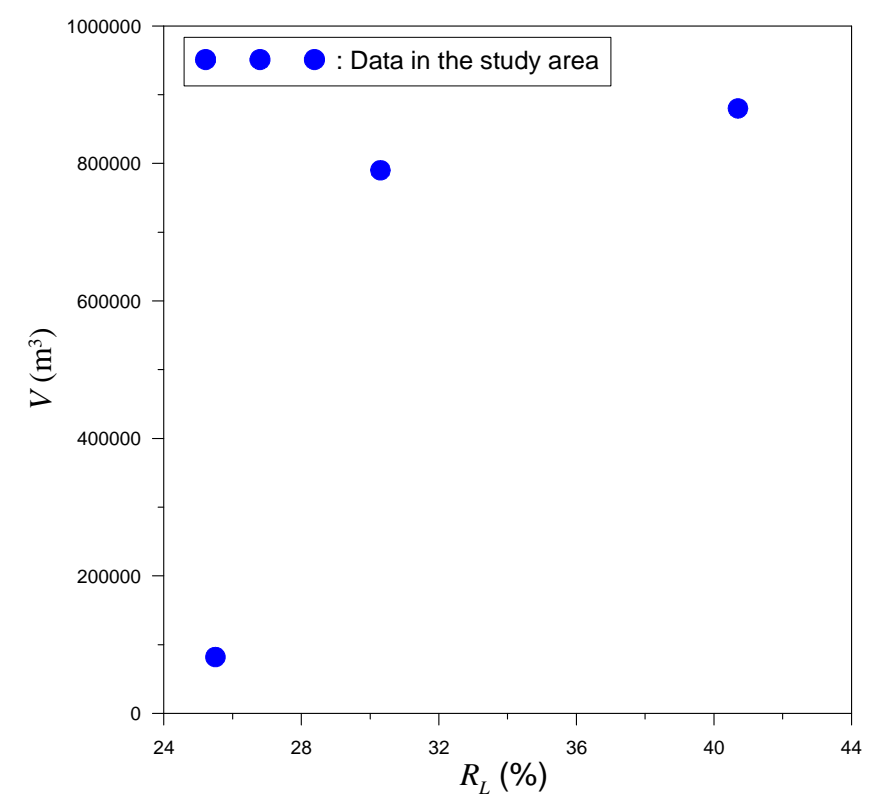

Figure 10. Relationship between debris-flow volume $V$ and landslide ratio $R_{\mathrm{L}}$ in the study area.

\section{Conclusions}

The debris-flow discharge is an important parameter for engineering planning design and evaluating the inundation area of debris flow. Because the debris-flow discharge is difficult to measure directly, a numerical simulation method was proposed to calibrate the discharge coefficient $c_{\mathrm{b}}$ (the ratio of the debris-flow discharge $Q_{\mathrm{dp}}$ to the water-flow discharge $Q_{\mathrm{wp}}$ ) of the debris flow and to determine the debris-flow discharge. Three debris-flow hazards in southern Taiwan caused by Typhoon Morakot in 2009 were selected as case studies for the discharge of landslide-induced debris flows. An inflow hydrograph assumed to be rectangular in shape and divided into two stages of sediment concentration $c_{\mathrm{V}}$ was used. The two parameters $c_{\mathrm{b}}$ and $c_{\mathrm{V}}$ involved in the inflow hydrograph were calibrated and presented. The calibrated values of $c_{\mathrm{b}}$ for the three gullies ranged from 6 to 18, and they tended to increase with an increase in the landslide ratio $R_{\mathrm{L}}$. The relationship between $c_{\mathrm{b}}$ and $R_{\mathrm{L}}$ was developed, and this can 


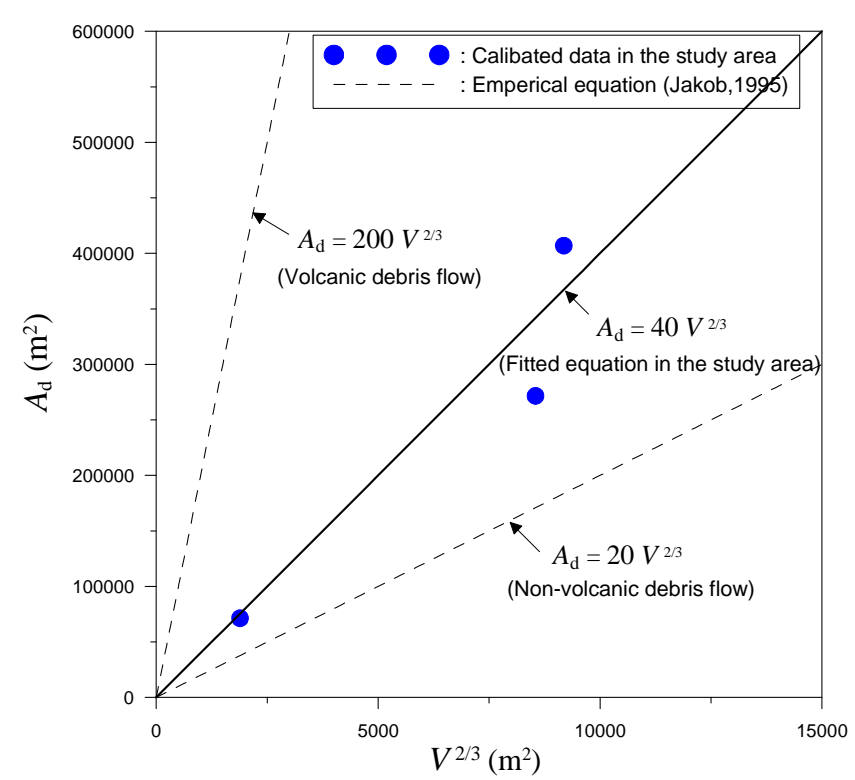

Figure 11. Relationship between deposition area $A_{\mathrm{d}}$ and debrisflow volume $V$.

be used for direct determination of the $Q_{\mathrm{dp}} / Q_{\mathrm{wp}}$ ratio when $R_{\mathrm{L}}$ is known. The value of $c_{\mathrm{b}}$ for high- $R_{\mathrm{L}}$-induced debris flows $\left(R_{\mathrm{L}}>30 \%\right)$ could exceed the bound of $c_{\mathrm{b}}=10$ for inchannel debris flows.

The empirical relationships between $Q_{\mathrm{dp}}$ and $Q_{\mathrm{wp}}$ were presented by collecting the data of $Q_{\mathrm{dp}}$ versus $Q_{\mathrm{wp}}$ from previous studies and using the data of $Q_{\mathrm{dp}}$ versus $Q_{\mathrm{wp}}$ in this study. $Q_{\mathrm{dp}}$ tends to increase with increasing $Q_{\mathrm{wp}}$. The upper bound for the relationship between $Q_{\mathrm{dp}}$ and $Q_{\mathrm{wp}}$ can be approximately expressed as $Q_{\mathrm{dp}}=40 Q_{\mathrm{wp}}$, and the lower bound is $Q_{\mathrm{dp}}=5 Q_{\mathrm{wp}}$; that is, $c_{\mathrm{b}}$ ranges from 5 to 40 . When $c_{\mathrm{b}}$ and $Q_{\mathrm{wp}}$ (estimated by a rational equation) are known, $Q_{\text {dp }}$ is determined by Eq. (1). Other empirical equations relating the debris-flow discharge in the study area, such as the $Q_{\mathrm{dp}}$ versus $V$ (debris-flow volume), and $A_{\mathrm{d}}$ (deposition area) versus $V$ (i.e., Eq. 9 and $A_{\mathrm{d}}=40 \mathrm{~V}^{2 / 3}$ ), were also presented and used as a comparison with previous studies. The empirical relationships developed in this study could be useful for determining the debris-flow discharge for engineering planning and evaluating the inundation area of a debris flow.

Acknowledgements. The authors thank the National Science Council of Taiwan for financial support. The data were kindly provided by the Soil and Water Conservation Bureau of Taiwan, National Cheng Kung University, National Taiwan University, and J. S. Wang, and M. L. Lin. The authors also appreciate C. J. Jeng, S. Y. Sun, and D. R. Su for their help in the field investigations, the handling editor K. Chang, the reviewer J. Sodnik, and three anonymous reviewers for their critical reviews and constructive comments.
Edited by: K. T. Chang

Reviewed by: four anonymous referees

\section{References}

Berti, M., Genevois, R., Simoni, A., and Tecca, P. R.: Field observation of a debris flow event in the Dolomites, Geomorphology, 29, 265-274, 1999.

Bovis, M. J. and Jakob, M:. The role of debris supply conditions in predicting debris flow activity, Earth Surf. Proc. Landf., 24, 1039-1054, 1999.

Calligaris, C. and Zini, L.: Debris flow phenomena: a short overview? Earth Sciences, Chap. 4, edited by: Imran Ahmad Dar, ISBN: 978-953-307-861-8, InTech., 2012.

Četina, M., Rajar, R., Hojnik, T., Zakrajšek, M., Krzyk, M., and Mikoš, M.: Case Study: Numerical Simulations of Debris Flow below Stože, Slovenia, J. Hydraulic Eng., 132, 121-130, 2006.

Chen, J. C., Jan, C. D., and Lee, M. S.: Reliability analysis of design discharge for mountainous gully flow, J. Hydraulic Res., 46, 835838, 2008.

Chen, J. C., Jeng, C. J., and Chuang, M. R.: Numerical simulation for landslides induced debris flow - a case study of Hong-shuixian gully in southern Taiwan, Sino-Geotechnics, 137, 40-47, 2013 (in Chinese).

Chow, V. T.: Open-Channel Hydraulics, McGraw-Hill, 1959.

Chow, V. T., Maidment, D. R., and Mays, L. W.: Applied Hydrology, McGraw-Hill, 1988.

Dai, J., Chen, W., and Zhou, B.: An experimental study of slurry transport in pipes, Proc. Int. Symposium on River Sedimentation, 195-204, 1980.

Fei, X. J.: Bingham yield stress of sediment water mixtures with hyperconcentration, J. Sediment Res., 3, 19-28, 1981 (in Chinese).

FLO-2D: FLO-2D Users Manual, Ver. 2009, FLO-2D Software Inc, Nutrioso, AZ, USA, 2009.

Griswold, J. P.: Mobility statistics and hazard mapping for nonvolcanic debris flows and rock avalanches, Master thesis, Portland State University, 2004.

Hsu, S. M., Chiou, L. B., Lin, G. F., Chao, C. H., Wen, H. Y., and $\mathrm{Ku}, \mathrm{C}$. Y.: Applications of simulation technique on debris-flow hazard zone delineation: a case study in Hualien County, Taiwan, Nat. Hazards Earth Syst. Sci., 10, 535-545, doi:10.5194/nhess10-535-2010, 2010.

Hungr, O., Morgan, G. C., and Kellerhals, R.: Quantitative analysis of debris torrent hazards for design of remedial measures, Can. Geotech. J., 21, 663-677, 1984.

Iverson, R. M., LaHusen, R., Major, J. J., and Zimmerman, C. L.: Debris flow against obstacles and bends: dynamics and deposits, EOS, Trans. Am. Geophys. Union, 75, 274, 1994.

Iverson, R. M., Schilling, S. P., and Vallance, J. W.: Objective delineation of lahar-inundation hazard zones, Geol. Soc. Am. Bull., 110, 972-984, 1998.

Jakob, M.: Debris-flow hazards analysis, in: Debris-flow hazards and related phenomena, edited by: Jakob, M. and Hungr, O., Springer-Praxis, Chichester, UK, 411-443, 2005.

Jan, C. D. and Shen, H. W.: Review dynamic modeling of debris flows, Recent Developments on Debris Flows, Lecture Notes Earth Sci., 64, 93-116, 1997.

Jan, C. D., Yu, C. Y., and Wu, Y. R.: A preliminary study on effect of sediment concentration on rheological parameters of sediment- 
water mixture, Proceedings of the First National Debris-Flow Conference, Nantou County, Taiwan, 179-190, 1997 (in Chinese).

Jitousono, T., Shimokawa, E., and Tsuchiya, S.: Debris flow following the 1994 eruption with pyroclastic flows in Merapi volcano, Indonesia, J. Jap. Soc. Erosion Control Engng 48 (Special Issue), 109-116, 1996.

Lin, J. Y., Yang, M. D., Lin, B. R., and Lin, P. S.: Risk assessment of debris flows in Songhe Stream, Taiwan, Eng. Geol., 123, 100112,2011

Lin, M.-L., Wang, K.-L., and Huang, J.-J.: Debris flow run off simulation and verification - case study of Chen-You-Lan Watershed, Taiwan, Nat. Hazards Earth Syst. Sci., 5, 439-445, doi:10.5194/nhess-5-439-2005, 2005.

Lin, Y. I., Jan, C. D., and Kuo, F. H.: Numerical Simulation of Debris Flow in Jiaopu Creek, Journal of the Taiwan Disaster Prevention Society, 5, 51-61, 2013 (in Chinese).

Melton, M. A.: The geomorphic and paleoclimate significance of alluvial deposits in Southern Arizona, J. Geol. 73, 1-38, 1965.

Mizuyama, T., Kobashi, S., and Ou, G.: Prediction of debris flow peak discharge, Proc. Int. Symp. Interpraevent, Bern, Switzerland, Bd. 4, 99-108, 1992.

O'Brien, J. S., Julien, P. Y., and Fullerton, W. T.: Two-dimensional water flood and mudflow simulation, J. Hydraul. Eng., 119, 244261, 1993

Pierson, T. C.: Flow behavior of channelized debris flows, Mt. St. Helens, Washington, in: Hillslope Processes, edited by: Abraham, A. D., Allen \& Unwin, Boston, 269-296, 1986.

PWRI: Technical standard for measures against debris flow (draft), Technical Memorandum of PWRI, No. 2632, Ministry of Construction, Japan, 1988.

Mikoš, M., Fazarinc, R., and Majes, B.: Delineation of risk area in Log pod Mangartom due to debris flows from the Stože landslide, Acta geographica Slovenica, 47, 171-198, 2007.

Rickenmann, D.: Empirical relationships for debris flows, Nat. Hazards, 19, 47-77, 1999.

Rickenmann, D. and Zimmermann, M.: The 1987 debris flows in Switzerland: documentation and analysis, Geomorphology, 8, 175-189, 1993.

Rickenmann, D., Weber, D., and Stepanov, B.: Erosion by debris flows in Field and laboratory experiments, Proceedings of the 3rd International conference on debris-flow hazards mitigation, edited by: Rickenmann, D. and Chen, C. L., Davos, Switzerland, Rotterdam, Millpress, 883-894, 2003.
Rickenmann, D., Laiglec, D., McArdell, B. W., and Hübl, J.: Comparison of 2D debris-flow simulation models with field events, Comput. Geosci., 10, 241-264, 2006.

Sodnik, J., Petje, U., and Mikoš, M.: Terrain topography and debrisflow modelling, Geodetski vestnik, 53, 305-318, 2009.

Sodnik, J. and Mikoš, M.: Modeling of a debris flow from the Hrenovec torrential watershed above the village of Kropa, Acta geographica Slovenica, 50, 59-84, 2010.

SWCB: Technical Handbook of Soil and Water Conservation, Soil and Water Conservation Bureau (SWCB), Taiwan, 2005 (in Chinese).

SWCB: Disasters caused by Typhoon Morakot in Taiwan, 2009, Soil and Water Conservation Bureau (SWCB), Taiwan 2009 (in Chinese).

Takahashi, T.: Debris Flow, IAHR Monograph, Balkema, Rotterdam, 1991.

Tecca, P. R., Genevois, R., Deganutti, A. M., and Armento, M. C.: Numerical modelling of two debris flows in the Dolomites (Northeastern Italian Alps), Debris-Flow Hazards Mitigation: Mechanics, Prediction, and Assessment, edited by: Chen, C. L. and Major, J. J., Millpress, Netherlands, 179-188, 2007.

VanDine, D. F.: Debris flow and debris torrents in the Southern Canadian Cordillera, Can. Geotech. J., 22, 44-68, 1985.

Wang, J. S.: Effects of sediment composition on debris flow rheological parameters, PhD thesis, National Cheng Kung University, Taiwan, 2007 (in Chinese).

WRA (Water Resources Agency): Report on the analysis of the rainfall brought by Typhoon Morakot in Taiwan, Ministry Economic Affairs of Taiwan, 1999.

Wu, J. S., Kan, Z. C., Tian, L. C., and Zhang, S. C.: Observational investigation of debris flow in the Jianglia gully. Yunnan, Science Publishing Co, 1-251, 1990 (in Chinese).

$\mathrm{Wu}, \mathrm{C} . \mathrm{H}$. and Chen, S. C.: The evaluation of the landslide potential prediction models used in Taiwan, J. Soil Water Conservation, 36, 295-306, 2004 (in Chinese).

Wu, C. H., Chen, S. C., and Chou, H. T.: Geomorphologic characteristics of catastrophic landslides during typhoon Morakot in the Kaoping Watershed, Taiwan, Eng. Geol., 123, 13-21, 2011. 